\title{
Extension of the High Temperature Limit of Cooling Geospeedometry
}

\author{
Kazuhito OzAwA* \\ 冷却地質速度計における高温限界の拡張 \\ 小澤 一仁*
}

\begin{abstract}
Geospeedometer proposed so far to estimate cooling history of rocks has a limit in terms of the maximum temperature above which we cannot deduce the history. The limit is governed by kinetic processes for geospeedometry and cooling rates; for example the olivine-spinel geospeedometry based on kinetics of $\mathrm{Mg}-\mathrm{Fe}^{2+}$ exchange between olivine and spinel with the maximum grain size of a few millimeters cannot record any cooling history above $800^{\circ} \mathrm{C}$ if the cooling rate is $<\sim 10^{-4}{ }^{\circ} \mathrm{C} /$ year. In order to extend the limit, a larger distance scale for geospeedometry is needed. By using mineralogical variations forming rock structures, whose distance scale is up to a meter order or more, we can in principle estimate thermal history of rocks up to their solidus temperatures, if effects of polycrystalline and multi-phase nature and the initial conditions for a large scale rock system are correctly assessed. The olivine-spinel geospeedometry was extended to deduce high temperature thermal history of a dunite-chromitite layer sampled from the Iwanai-dake peridotite mass, Hokkaido. The Fe-Mg variation over $6 \mathrm{~cm}$ in dunite from the contact is analyzed by a 1-D diffusion model with a composition-dependent diffusivity and a changeable cooling rate. The dunite-chromitite geospeedometry indicates that the Iwanai-dake mass was cooled from $\sim 1000^{\circ} \mathrm{C}$ to $900^{\circ} \mathrm{C}$ with increasing cooling rate from $<0.01^{\circ} \mathrm{C} /$ year to $\sim 0.3^{\circ} \mathrm{C} /$ year. This suggests that the slower cooling after the melting event was followed by the ascent of the mass that resulted in the inferred rapid cooling at $\sim 900^{\circ} \mathrm{C}$.
\end{abstract}

\section{Introduction}

For better understanding of transportation processes within the earth, temperature and pressure history of rocks that brought up to the earth's surface by various processes provides useful information. P-T history of rocks can be obtained by applying geospeedometry ${ }^{1)-3)}$, which utilizes kinetics of various reactions that proceed responding to changes in pressure and temperature conditions at a certain rate. For each geospeedometry, we have to know the mechanism of raction and how fast the reaction proceeds in a given reange of temperature. In this paper, one of the simplest types of geospeedometry, which is based on a diffusion-controlled cation exchange reaction between two coexisting minerals without boundary

1998年 7 月 1 日受理

* 岡山大学固体地球研究センター

Institute for Study of the Earth's Interior, Okayama University, 827 Yamada, Misasa, Tottori 682-0193, Japan migration is discussed ${ }^{4)-6)}$.

Geospeedometry based on cation exchange reactions has a limit in the inferable maximum temperature for a given range of size of minerals and a cooling rate. For example, application of the olivine-spinel geospeedometry ${ }^{2}$ to slowly cooled rocks does not give thermal history above $800^{\circ} \mathrm{C}$, because the size of isolated spinel grains is smaller than a few millimeters in general. The aim of this paper is to propose a way to extend the upper limit for slowly cooled rocks, ideally up to the solidus temperature by simply extending the size of reaction space up to $10 \mathrm{~cm} \sim 1 \mathrm{~m}$. The way to overcome difficulties in extending the distane scale is discussed and the method is applied to a dunite-chromitite composite sample.

\section{Closure Temperature}

Closure temperature $\left(T_{c}\right)$, which is defined as the temperature of the system at the time when the composition involved in a reaction does not change 
anymore during cooling, was formulated by Dodson $^{7)}$ as follows,

$$
\frac{E}{R T_{c}}=\ln \left(-\frac{A R T_{c}^{2} D_{0} / a^{2}}{E \dot{T}}\right)
$$

where $D_{0}$ is the diffusion pre-exponential factor, $E$ is the activation energy for the diffusion process, $\dot{T}$ is the cooling rate (negative value for cooling), $a$ is a characteristic dimension of the system (e.g., grain size), and $A$ is a numerical constant depending on geometry (e.g., 55 for sphere ${ }^{7)}$ ).

Dodson's equation was formulated for a diffusional exchange of minor components between a mineral and a faster diffusing infinite reservoir, which could be a grain boundary phase or adjacent minerals. Ehlers and Powell ${ }^{8}$ ) empirically modified Dodson's equation for a exchange reaction of major components between two minerals with finite sizes. They proposed the following expression for the closure temperature,

$$
\frac{E}{R T_{c}}=\ln \left(-\alpha \frac{A R T_{c}^{2} D_{0} / a^{2}}{E \dot{T}}\right)+\beta\left(1+\frac{1}{r k}\right)
$$

where $r$ is the ratio of size of two minerals, $k$ is the apparent distribution coefficient calculated by core-core pair of the two minerals. The parameters $\alpha$ and $\beta$ were determined by numerical experiments to be 2.56 and 1.72 , respectively.

\section{Possible Methods for Maximization of Closure Temperature}

In this section, ways to increase $T_{c}$ for diffusioncontrolled exchange reactions with cooling rate as low as $\sim 10^{-4} \mathrm{C} /$ year, which is the slower estimated cooling rate of intrusive peridotites by olivinespinel geospeedometry ${ }^{2)}$, are considered. Equation (1) shows that parameters adjustable to increase the closure temperature are $D_{0}, E$, and $a$. The variation of parameter $A$ is confined between 2 to $60^{9}$ ). Because there is the compensation law ${ }^{10), 11)}, D_{0}$ $\left(\mathrm{m}^{2} / \mathrm{sec}\right)$ and $E(\mathrm{~kJ} / \mathrm{mole})$ are not independently adjustable and are related by the equation

$$
\log D_{0}=a_{1} E+a_{2},
$$

where $a_{1}$ and $a_{2}$ are constants.

Under such constraints, relationship between cooling rate and closure temperature is schematically illustrated in Fig. 1. Due to the common grain size of natural rocks $(1 \mu \mathrm{m}-1 \mathrm{~mm})$ and the com-

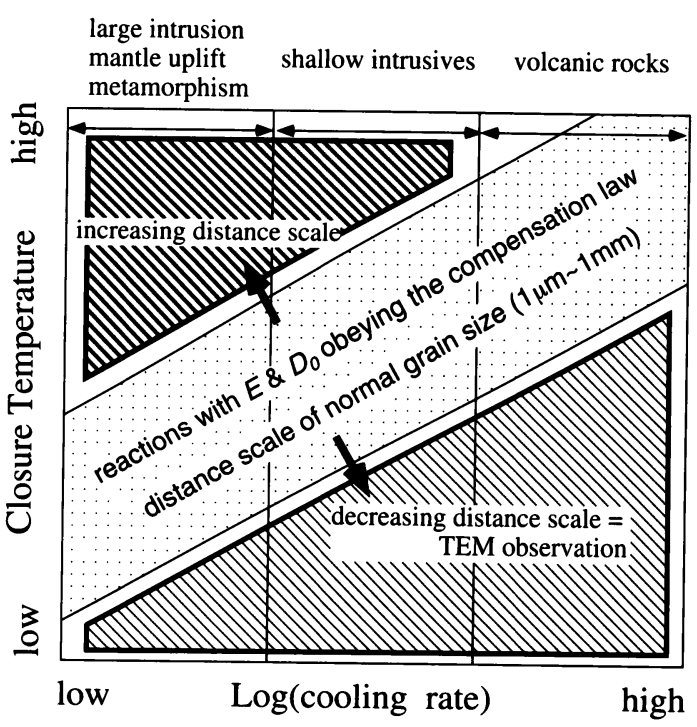

Fig. 1 Schematic illustration of relationship between closure temperature and cooling rate. The dotted region represents the window through which we can know cooling history of rocks by common geospeedometry utilizing a reaction with a normal activation energy and distance scale. By decreasing the distance scale as small as the TEM scale, high cooling rate at low temperatures can be detected. Low cooling rate at high temperatures can be estimated by increasing the distance scale.

pensation law with ordinary range of activation energy (40-800 kJ/mole ${ }^{12), 13)}$ ), a region where we can estimate a cooling rate for a given closure temperature is limited (dotted region in Fig. 1). Unless there is a reaction with anomalously high activation energy, we have to increase or decrease the distance scale to infer thermal history above or beneath this region. By decreasing the distance scale to submicrons, large cooling rates at low temperature (lower right region in Fig. 1) can be estimated. This can be done by transmission electron microscopy (TEM; e.g., Fujino et al. ${ }^{14)}$ ). By increasing the distance scale up to a meter or more, small cooling rates at high temperature (upper left corner in Fig. 1) may be estimated. This extension of the distance scale has not yet established as a useful geospeedometry for high temperature thermal history at low rate, in contrast to the successful application of the TEM technique to low temperature geospeedometry.

High temperature thermal history of slowly cooled rocks is examined quantitatively in Fig. 2, which shows the effect of activation energy on the 
(a)

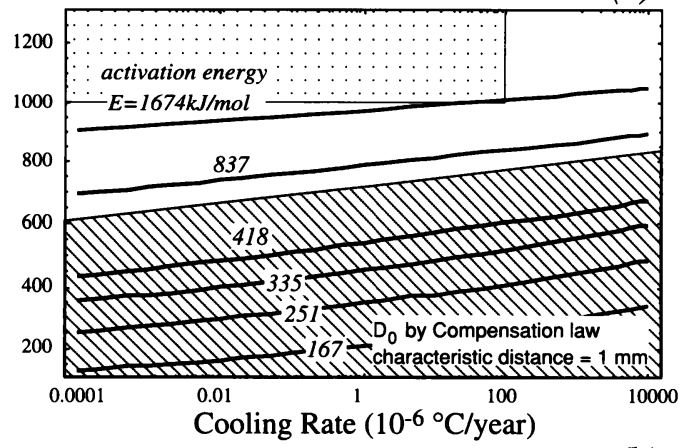

(b)

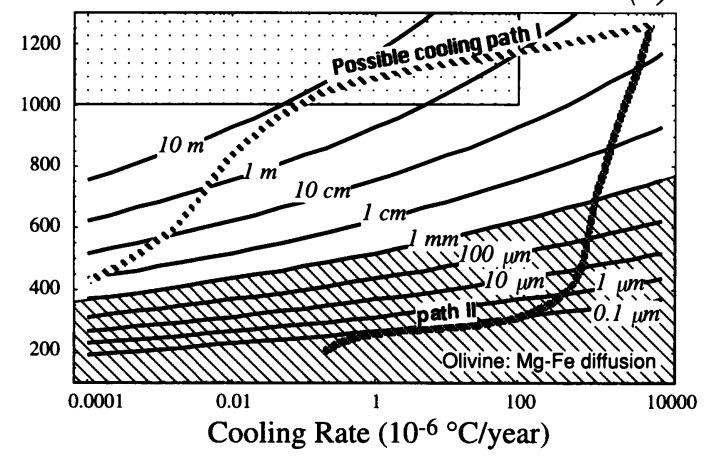

Fig. 2 Relationship between cooling rate and closure temperature for different activation energies and a $1 \mathrm{~mm}$ distance scale (a) and for various characteristic distance scale and $\mathrm{Mg}-\mathrm{Fe}$ diffusion in olivine (b). The obliquely ruled areas show the range of the possible activation energy in (a) and that of common grain size in natural rocks in (b). Dotted areas show the ranges of temperature and cooling rate that are targeted in this paper. In (a) the compensation law is assumed (see text). In (b) two thick curves are for two extreme cases of thermal history with changing rate of cooling. The Mg-Fe interdiffusion coefficient in olivine is after Misener ${ }^{15)}$. If the diffusivity by Chakraborty ${ }^{16)}$ is used, closure temperatures are higher by $100^{\circ} \mathrm{C}$ than shown in (b) for cooling rate of $10^{-6 \circ} \mathrm{C} /$ year and grain size of $1 \mathrm{~m}-1 \mathrm{~cm}$.

relationship between closure temperature and cooling rate. The two constants $a_{1}=3.46 \times 10^{-2}$ and $a_{2}=$ $-9.94^{10)}$ are used in eq. (3). In order to increase closure temperature up to $1000^{\circ} \mathrm{C}$ for cooling rate less than $10^{-4}{ }^{\circ} \mathrm{C} /$ year and for a grain with $1 \mathrm{~mm}$ size (dotted region at the upper left corner of Fig. $2 a)$, the activation energy should be higher than $1600 \mathrm{~kJ} / \mathrm{mole}$, which is anomalously large for diffusion in oxide and silicate minerals ${ }^{12), 13)}$. Therefore, it will be necessary to increase the distance scale in order to obtain information at high temperatures for slowly cooled rocks.
Figure $2 \mathrm{~b}$ shows the relationship between cooling rate and closure temperature for $\mathrm{Mg}-\mathrm{Fe}$ olivine with various sizes. If the grain size is less than $1 \mathrm{~mm}$ (obliquely ruled area), then the maximum inferable temperature is as high as $700^{\circ} \mathrm{C}$ at cooling rate of $10^{-3 \circ} \mathrm{C} /$ year for path II, but it is $400^{\circ} \mathrm{C}$ for path I. For slowly cooled rocks represented by path $\mathrm{I}$, the maximum grain size of $1 \mathrm{~mm}$ is a tremendous obstacle to deduce the thermal history. It is clear that if the distance scale is several tens centimeters, then we may be able to detect cooling rate of $\sim 10^{-4}{ }^{\circ} \mathrm{C} /$ year at temperatures as high as $1000^{\circ} \mathrm{C}$. Because the $\mathrm{Mg}$-Fe diffusion in olivine is relatively fast compared to diffusion of other cations in major rock forming minerals, we can reduce the size to the order of a few to several tens centimeters if we use other reactions.

\section{Problems in Extending Distance Scale for Diffusional Geospeedometry}

Because common minerals with a meter or even centimeter size are very rare, there are several obstacles to increase the distance scale in slowly cooled rocks. At first, a polycrystalline and/or multi-phase rock system has to be treated. Polycrystals introduce grain boundaries, which can be neglected only if one mineral is completely included in another mineral. As far as the inter-phase boundaries between contacting two minerals are connected from a grain boundary network, there is a possibility of material influx from the fast path network. This effect on the contacting mineral pair can be evaluated by carefully examining zoning profiles of the minerals and larger scale structures (veins, layering, schistosity, etc.) and associated heterogeneities in the rock. By contrast, the distance scale of diffusion is inevitably larger than the grain size in the extension of the distance scale for geospeedometry, and diffusion through polycrystalline aggregate with grain boundaries and inter-phase boundaries has to be correctly evaluated. Polycrystalline nature also introduces either random or preferred orientation of mineral grains with diffusional anisotropy. For a grain size scale, the orientation of each grain can be specified and a suitable diffusivity along the direction of the measurement can be used. In the case of polycrystalline minerals with diffusional anisotropy, however, there are many possible paths with various diffusivities. 
In addition to the aformentioned difficulties for a single phase system, a multi-phase system has other complexities such as, inter-phase boundary, variable diffusion coefficients and the anisotropy depending on minerals, elemental partitioning among minerals, variable molar concentration of a diffusing component (component density ${ }^{17)}$ ), modal change due to net-transfer reactions, and complex microstructures. In polycrystalline and multi-phase rocks, grain boundaries or inter-phase boundaries may be partially filled with fluid, such as silicate melt or $\mathrm{H}_{2} \mathrm{O}$ or $\mathrm{CO}_{2}$-rich fluid. The presence of such fluid phase not only adds the aforementioned complexities as in the case of addition of a new mineral phase but also plays a significant role in mass transport, because they can advect along the pressure gradient if their connectivity is attained. Furthermore, grain or inter-phase boundaries are not unique path for fluid migration, but cracks, whose orientation and number density could dynamically change, may be more effective.

Finally, the initial condition, which we need to know in order to extract P-T history, becomes more ambiguous if the distance scale is increased. In the case of distance scale less than a millimeter, higher temperature stage usually erases most of the heterogeneity before the closure temperature is approached. Thus, homogeneous initial condition at a certain temperature can be assumed. Dodson ${ }^{7)}$ noted that geospeedometry is independent of the starting temperature if it is sufficiently high to reach complete homogenization and equilibrium (also see Ozawa $^{2)}$ ). However, complete homogenization of more than $10 \mathrm{~cm}$ scale usually cannot be expected because it requires very long time (up to $\sim 0.1 \mathrm{Ga}$ ) to attain the homogeneity. The initial mineralogical variation in rocks, therefore, should be estimated by additional information from the rocks.

\section{Qualitative Evaluation of the Problems in Geospeedometry}

As shown above, there are many problems that should be solved before successful extension of the distance scale for a geospeedometry. All these problems cannot be evaluated in this paper, but several critical points are discussed.

\section{1 Grain boundary and inter-phase boundaries}

Grain boundary is an important path for mass transportation, of which role in diffusive mass

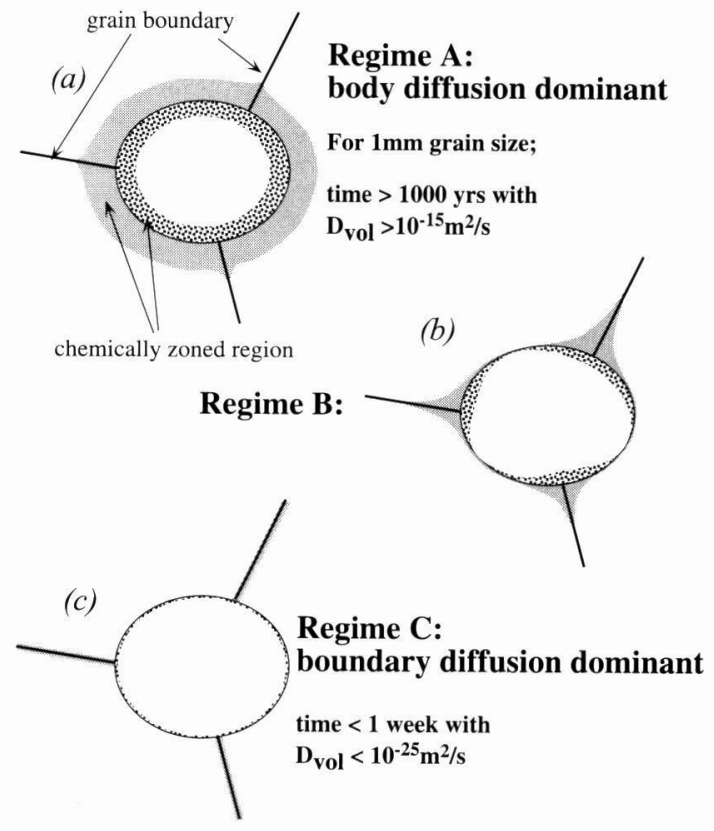

Fig. 3 Three diffusion regimes in polycrystals after Harri$\operatorname{son}^{20)}$. Harrison's model was illustrated for cation exchange reactions between a single crystal and surrounding polycrystals of another mineral. The shaded area represents the region where the concentration of an exchange component is higher (or lower) than a certain value. The boundary values (time and lattice diffusivity) of regimes $\mathrm{A}$ and $\mathrm{B}$ and that between regimes $\mathrm{B}$ and $\mathrm{C}$ are after Joesten $^{18)}$.

transfer has been discussed and reviewed by several authors in the earth science field ${ }^{17), 18)}$ and in the material science filed ${ }^{19}$ ). Brady ${ }^{17)}$ regarded a mono-mineralic rock as a two-phase system by treating grain boundary as the secondary phase. Effective diffusivities can be expressed as a function of diffusivities of the two phases, the volume ratio (very small volume fraction for grain boundary), and configuration of grain boundaries (e.g., parallel or series). He stressed that the grain size of a rock is the most important textural parameter that affects intergranular diffusion because smaller crystals generate more intergranular paths per unit cross section. He also pointed out the importance of width of the intergranular region.

Joesten ${ }^{18)}$ reviewed grain-boundary diffusion in silicate and oxide minerals. He introduced the Harrison mode1 ${ }^{20}$, which defined the three regimes for grain boundary and lattice diffusions in a polycrystal system with grain boundary net- 
work (Fig. 3). Figure 3 illustrates the three regimes of Harrison ${ }^{20}$ ) for a diffusion controlled exchange reaction between an isolated mineral grain and its surroundings (e.g., spinel in dunite). In regime $\mathrm{A}$ the diffusion length in the lattice is large compared with the grain size; in regime B the diffusion length in the lattice is smaller than the grain size; in regime $\mathrm{C}$ the diffusion length in the lattice is negligible, and diffusion occurs only along the grain boundary network. Joesten ${ }^{18}$ ) pointed out the importance of time (for isothermal conditions) in addition to the length scale of lattice diffusion and delineated the region for three types of diffusion kinetics in the diagram of time vs. lattice diffusivity.

In these reviews and previous work cited therein, constant diffusivity and thus a constant temperature were assumed. In order to evaluate the role of grain boundary diffusion for geospeedometry, the temperature-dependent (i.e., time-dependent) diffusivity has to be taken into consideration. A problem to be addressed is how elemental distribution in a rock with a macro-structure, as shown in Fig. 4a as an example, is frozen in during cooling. This problem is simplified as shown in Fig. 4b. Diffusion equations and boundary conditions in two dimensions are derived as follows,

$$
\begin{aligned}
& \frac{\partial C^{A}}{\partial t}=D^{A}(t)\left\{\frac{\partial^{2} C^{A}}{\partial x^{2}}+\frac{\partial^{2} C^{A}}{\partial y^{2}}\right\} \\
& \frac{\partial C^{g b}}{\partial t}=D^{g b}(t) \frac{\partial^{2} C^{g b}}{\partial y^{2}}-\frac{2 D^{A}(t)}{\delta}\left(\frac{\partial C^{A}}{\partial x}\right)_{x=0} \\
& C^{A}(x, 0, t)=C^{g b}(0, t)=C^{B} \\
& C^{A}(x, \infty, t)=C^{g b}(\infty, t)=C^{0} \\
& \left.\frac{\partial C^{A}}{\partial x}\right)_{x=\frac{L}{2}}=0
\end{aligned}
$$

where $C^{A}$ and $D^{A}$ are concentration and diffusivity in the crystal A, $C^{g b}$ and $D^{g b}$ are the concentration and diffusivity along the grain boundary, $\delta$ is the thickness of the grain boundary, $L$ is the width of the crystal, $C^{0}$ is the initial concentration in A, and $C^{B}$ is the fixed concentration at $y=0$. Eq. (5) is the diffusion equation along the grain boundary ${ }^{19), 21)}$ and can be regarded as a boundary condition for lattice diffusion in crystal A at $x=0$. The grain boundary thickness is supposed to be negli-
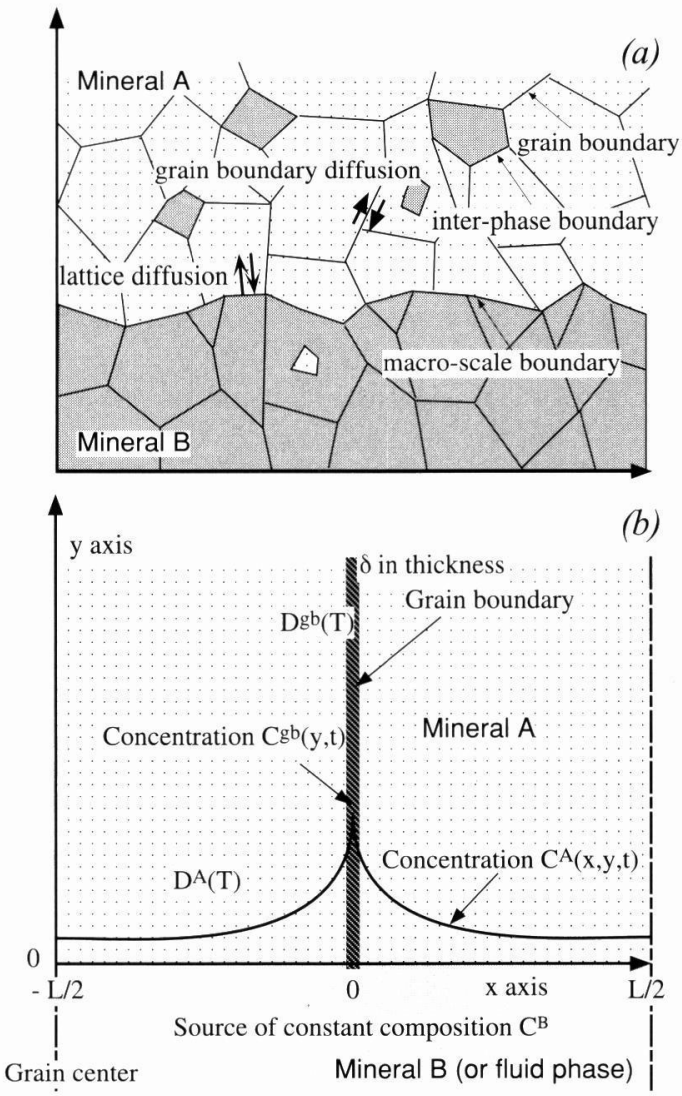

Fig. 4 Two dimensional grain boundary and inter-phase boundary model for elemental redistribution in a twophase rock with a layer structure. (a) Banded two-phase rocks with sharp modal change at the layer boundary, and (b) extreme simplification of the two-phase model. In (b) thickness of the grain boundary is assumed to be significantly small as compared with the size of the grain. See text for the notations in (b).

gibly small as compared to the size of crystal, which is usually the case. The last term of the right hand side of (5) represents the sink term due to leaking from the boundary region to the crystal.

The boundary condition (6) assumes; (1) mineral B (or a fluid phase) has very large diffusivity of the component and is large enough as an infinite reservoir, and (2) partition coefficient of the component between $\mathrm{A}$ and $\mathrm{B}$ is constant. If diffusivity in mineral $\mathrm{B}$ is not so large and the partition coefficient between A and B is time dependent, a diffusion equation has to be solved for mineral $\mathrm{B}$ with appropriate boundary conditions along the A -B interphase boundary. 
After introducing compressed time $\tau^{1)}$,

$$
\tau=\int_{0}^{t} D^{A}(t) d t / D^{A}(0)
$$

where is the initial diffusion coefficient, the diffusion equation and boundary conditions (4) - (8) are nondimensionalized. Because the effect of grain boundary diffusion in a coarse-grained rock is examined in this paper $\left(\delta^{2} / D^{g b} \ll L^{2} / D^{A}\right)$, the problem may be regarded semi-infinite in both $\mathrm{x}$ and $\mathrm{y}$ directions. Therefore, the maximum compressed time $\tau_{\max }$ and the maximum diffusion distance $l_{\max }$,

$$
\tau_{\max }=\int_{0}^{\infty} D^{A}(t) d t / D^{A}(0), l_{\max }=\sqrt{\int_{0}^{\infty} D^{A}(t) d t},
$$

are chosen as time and distance scales. The composition is scaled by $C^{0}-C^{B}$. The nondimensionalized equations are obtained as follows after dropping prim,

$$
\begin{aligned}
& \frac{\partial C^{A}}{\partial t}=\frac{\partial^{2} C^{A}}{\partial x^{2}}+\frac{\partial^{2} C^{A}}{\partial y^{2}} \\
& \frac{\partial C^{g b}}{\partial t}=\Delta^{g b}(\tau) \frac{\partial^{2} C^{g b}}{\partial y^{2}}-\zeta \Delta^{A}(\tau)\left(\frac{\partial C^{A}}{\partial x}\right)_{x=0} \\
& C^{A}(x, 0, \tau)=C^{g b}(0, \tau)=1 \\
& C^{A}(x, \infty, \tau)=C^{g b}(\infty, \tau)=0 \\
& C^{A}(-\infty, y, \tau)=C^{g b}(+\infty, y, \tau)=0
\end{aligned}
$$

where $\zeta=2 l_{\max } / \delta, \Delta^{A}(t)=D^{A}(t) / D^{A}(0)$, and $\Delta^{g b}(t)$ $=D^{g b}(t) / D^{A}(0)$ are dimensionless parameters. The last two dimensionless parameters are time-dependent and represent the change of diffusivities during cooling.

Because the boundary condition (5') for the two dimensional diffusion problem in mineral $\mathrm{A}$ is a diffusion equation in itself, the equations (4') (8') may not have a simple analytic solution, and they were solved numerically by implicit alternating-direction method (IAD ${ }^{22)}$ ). The results are shown in Figs. 5 and 6. In Fig. 5, development of zoning near a grain boundary during isothermal heating at $1000^{\circ} \mathrm{C}$ and cooling from $1000^{\circ} \mathrm{C}$ at $0.1^{\circ} \mathrm{C} / \mathrm{sec}$ is compared. In the isothermal condition, the zoning becomes less pronounced after long duration and the profile becomes less steep with time (Fig. 5a; see also Fig. 4 of Joesten ${ }^{18}$ ) based on Fisher solution ${ }^{21)}$ ). By contrast, the gra-
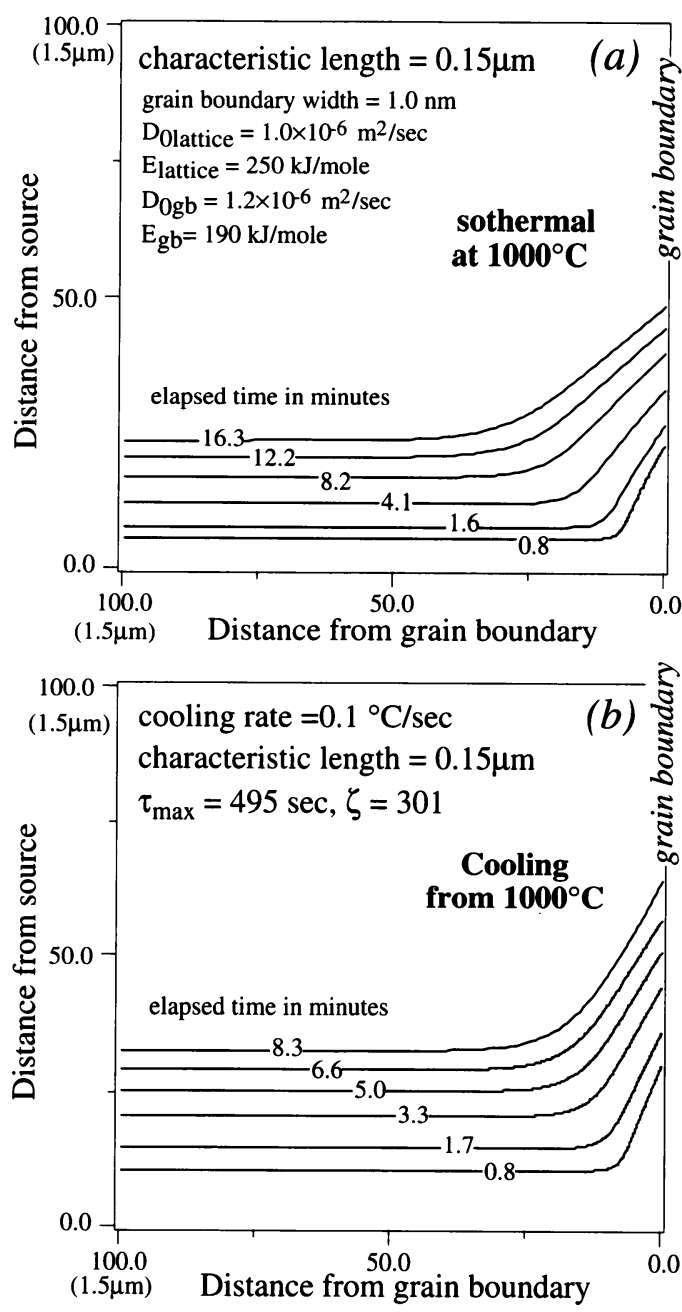

Fig. 5 Development of chemical zoning near a grain boundary during isothermal heating at $1000^{\circ} \mathrm{C}$ (a) and cooling from $1000^{\circ} \mathrm{C}$ with a rate of $0.1^{\circ} \mathrm{C} / \mathrm{sec}$ (b). Contours of constant concentration (0.02) are drawn for several elapsed time steps indicated by numbers on each contour. The used parameters for activation energy and pre-exponential term for grain boundary diffusion are shown in (a).

dient near the grain boundary does not change much during cooling until it is completely frozen (Fig. 5b). For a given $\zeta$ value, a frozen zoning profile near grain boundary becomes more remarkable as $\Delta^{g b}(t)$ becomes large (compare Figs. $6 \mathrm{~b}$ and $6 \mathrm{~d})$. On the contrary, for a given $\Delta^{g b}(t)$, $\Delta^{A}(t)$, and grain boundary width, the zoning is more pronounced as cooling rate increases (as $\zeta$ value decreases) (compare Figs. 6a, b, and c). 


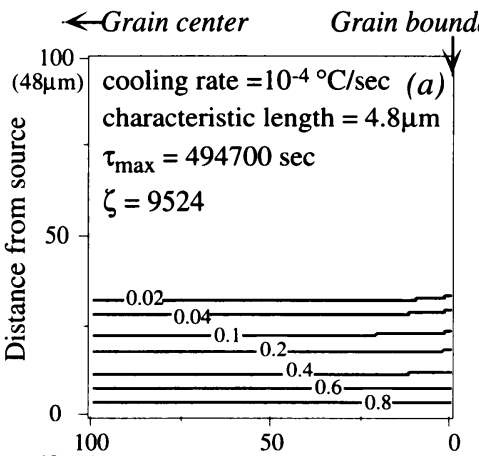

$(48 \mu \mathrm{m})$ Distance from grain boundary

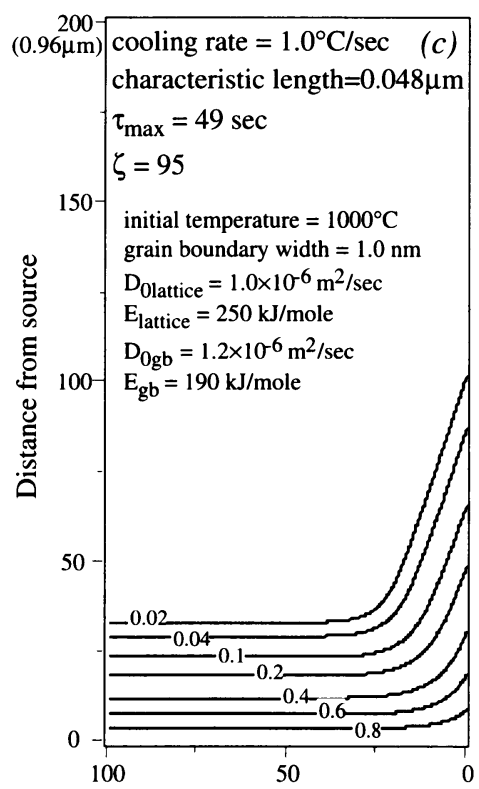

$(0.48 \mu \mathrm{m})$ Distance from grain boundary

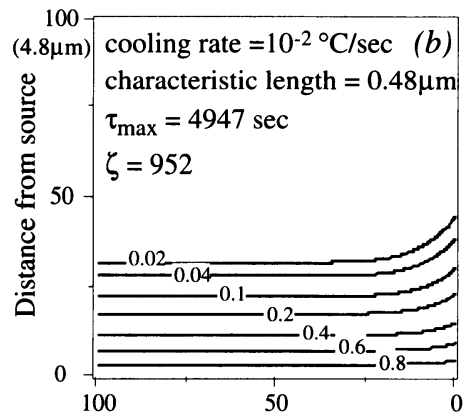

$(4.8 \mu \mathrm{m})$ Distance from grain boundary

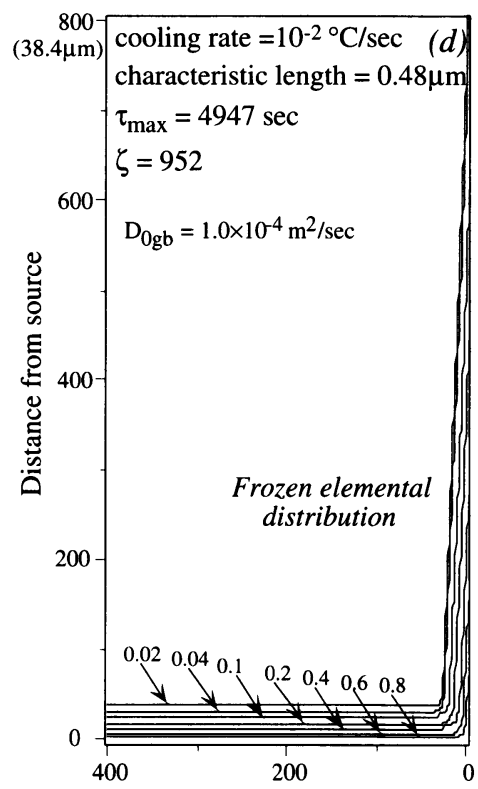

$(19.2 \mu \mathrm{m})$ Distance from grain boundary

Fig. 6 Frozen elemental distribution near a grain boundary during cooling at various rates from $1.0^{\circ} \mathrm{C} / \mathrm{sec}$ to $10^{-4}{ }^{\circ} \mathrm{C} / \mathrm{sec}(\mathrm{a}, \mathrm{b}$, and $\mathrm{c}$ ). Parameters used in the calculation are shown in the panel (c). In (d), effect of grain boundary diffusion is shown under the same conditions as used in (b) except for the pre-exponential term for grain boundary diffusion. Both axes are normalized to the maximum diffusion distance, which depends on cooling rate, thus the actual scale of each panel decreases from (a) to (c).

Such behavior of lattice diffusion near grain boundaries is governed by the relative importance of the grain boundary diffusion term and leakage term in $\left(5^{\prime}\right)$, which is characterized by the parameter $\zeta^{\prime}=\zeta \Delta^{A}(\tau) / \Delta^{g b}(\tau)=\zeta D^{A}(\tau) / D^{g b}(\tau)$.

If $\zeta^{\prime}$ is small, then there is no leakage from the grain boundary and only grain boundary diffusion takes place (Fig. 6d). This corresponds to Harrison's grain boundary diffusion kinetic regime $\mathrm{C}$. By contrast, if $\zeta^{\prime}$ is significantly large, extensive

leakage takes place and the grain boundary region is always buffered by the diffusive flux from the surrounding crystal (Figs. 6a). This is Harrison's kinetic regime A. If $\zeta^{\prime}$ is close to unity, then the leakage and diffusion along grain boundary are competing (Figs. 6b and c), which is the situation of Harrison's regime B. During cooling, $\zeta^{\prime}$ decreases because the activation energy of grain boundary diffusion is much smaller than that of the lattice diffusion. This is the reason why the gradient near grain boundary does not change significantly during cooling (Fig. $5 b)$.

Figure 6 shows that if grain boundary width is a few $\mathrm{nm}$ and $\Delta^{g b}(t)$ is $\sim 10^{5}$ (as in the case of olivine), grain boundary diffusion does not affect diffusional mass transport in a polycrystalline material during a cooling process unless the grain size is significantly smaller than $\sim l_{\max } / 5$. If the cooling rate is $0.01^{\circ} \mathrm{C} /$ year, then $l_{\text {max }} / 5$ is $539 \mu m$, which is still as large as the naturally observed grain size in peridotite $(\sim 1 \mathrm{~mm})$. Furthermore, as cooling rate decreases, leakage to the adjacent crystal dominates over grain boundary diffusion due to large $\zeta$ value, which results in the diffusion kinetics of regime A (Fig. 6). It is summarized that as far as the average grain size of olivine is larger than a few hundreds $\mathrm{mm}$, grain boundary diffusion does not play an important role in diffusive mass transfer in slowly cooled peridotites.

\section{2 Multi-phase problems}

The problems in application of geospeedometry to a multi-phase system are rather classical and have been studied as diffusion problems in hetero- 
geneous media ${ }^{23), 24)}$. Even in a two-phase system the effective diffusivity is strongly dependent on mineral mode, grain size, and morphology of the interface ${ }^{17)}$. Therefore, there is a limitation in application of the effective diffusivity because microstructures of natural rocks are very complicated and the number of phases present in those rocks are usually more than two. Numerical approach may be the unique method to precisely evaluate diffusion in a multi-phase system ${ }^{24}$ ). Presence of phases with zero or very low concentration of a component used for geospeedometry, such as plagioclase in mafic rocks for $\mathrm{Mg}$-Fe components, makes the geospeedometry complicated for application, but has also an advantage to increase tortuosity ${ }^{25}$, which can increase the effective distance scale and thus the closure temperature.

\section{3 Initial condition problems}

Initial condition is the most difficult problem, which should be properly treated for each case considering processes by which the rock had formed before it started to cool. In the following section, geospeedometry for a multi-phase system will be applied to peridotites and the initial condition needed for the application is briefly mentioned here. For the initial condition of a peridotite, we cannot simply assume homogeneity in mineral phases at a certain high temperature. The real initial conditions should be the stage when magmatic processes had come to the end and the rock started to cool. Therefore, we have to invert magmatic processes that formed the structure used for geospeedometry and cooling process simultaneously.

\section{Application}

Geospeedometry using macro-structures is applied to a chromitite-dunite composite sample from the Iwanai-dake peridotite mass, Hokkaido. This unrooted sample is $10 \mathrm{~cm}$ in size consisting of $1 / 4$ of chromitite and 3/4 of dunite (Fig. 7). Chromitite contains more than 90 vol\% chromite and interstitial olivine with minor chlorite. Dunite consists mostly of olivine with minor spinel grains and secondary phases such as tremolite and diopside along veins. The sample is suitable for a macro scale geospeedometry because chromite and dunite can be regarded as monomineralic, which greatly simplifies the procedure for geospeedometry.

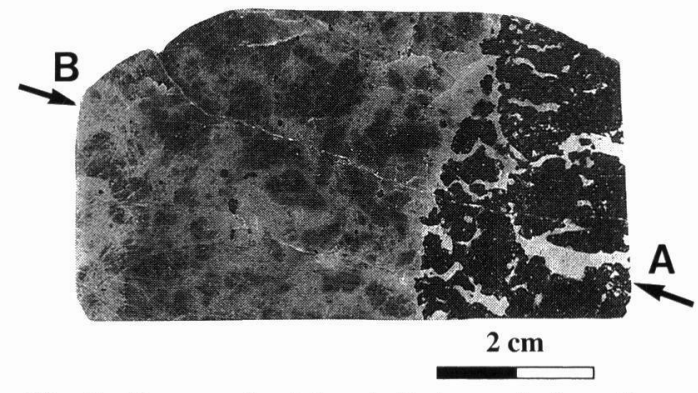

Fig. 7 Photograph of the studied sample from the Iwanai-dake mass, Hokkaido. The black portion on the right is chromitite with interstitial olivine and the gray part on the left is dunite with minor spinel. The profile shown in Fig. 8a is along A-B.

Figure 8 shows variations of Fo mol. $\%$ and $\mathrm{NiO}$ wt. $\%$ in olivine across the boundary of the chormitite and dunite layers (Fig. 7). Olivine in the dunite becomes strongly rich in Fo mol.\% and $\mathrm{NiO}$ wt.\% toward the boundary with the chromitite. The variation is observed over the distance scale of 6 centimeters, which is significantly large as compared with the zoning in olivine around a millimeter size chromite ${ }^{26)}$. The remarkable enrichment of $\mathrm{Mg}$ and $\mathrm{Ni}$ in olivine in and near the chromitite (Figs. 8) indicates that their variation is principally due to the $\mathrm{Mg}-\mathrm{Fe}-\mathrm{Ni}$ exchange between the dunite and chromitite layers during cooling. This is because $\mathrm{Mg}$ and $\mathrm{Ni}$ are preferentially partitioned into olivine at low temperature as compared to $\mathrm{Fe}^{27), 28)}$. Therefore, the zoning can be used to estimate high temperature thermal history. Locally, very Fo-rich and $\mathrm{NiO}$-rich veinlike regions are present, which is attributable to the late stage modification along fractures (at very low temperature possibly with fluid influx). This is consistent with the occurrence of diopside and tremolite along such Mg-rich veins.

Figure 9a shows modeled zonings with the observed Fo variation shown in Fig. 8. The model is one dimensional and assumes two monomineralic layers contacting with flat interface. The model further assumes rapid diffusion in chromitite, kinetic regime A, Fo 92.4 as initial olivine composition, $1000^{\circ} \mathrm{C}$ initial temperature. These assumptions are assessed or explained below.

The assumption of rapid diffusion in the chromitite may not be completely satisfied because of the smaller diffusivity in Cr-rich spinel ${ }^{2)}$, but 

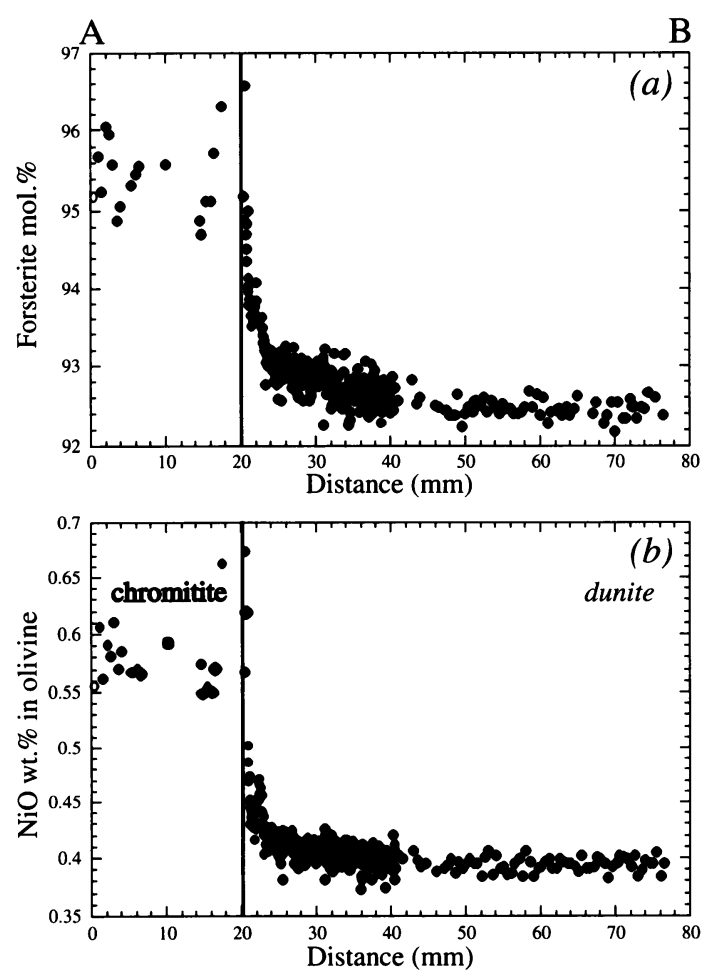

Fig. 8 Variation of Fo mole\% (a) and $\mathrm{NiO}$ wt\% (b) in olivine across the dunite-chromitite contact from the Iwanai-dake mass, Hokkaido, Japan (along A-B in Fig. 7). The contact is located at $20 \mathrm{~mm}$. The data clearly related to the secondary process forming hydrous veins are omitted.

gives the maximum cooling rate estimation. The regime $\mathrm{A}$ assumption is not correct, but the late stage low-temperature disturbance is spiky, suggesting that the smoothed lower bound give the frozen A regime profile (Fig. 8). The assumed initial value of Fo 92.4 dunite has no clear supporting evidence, but the minimum Fo value in the dunite layer was taken. The initial value could be lower than 92.4, and thus the assumption gives the maximum estimate for the cooling rate. The initial homogeneity is suggested by the convex downward positive correlation between $\mathrm{Fo}$ and $\mathrm{NiO}$ content in olivine, which may be attributable to the slower diffusivity of $\mathrm{Ni}$ in olivine ${ }^{30}$ ). The initial temperature is the maximum calculated temperature with a pair of large spinel in chromitite and the most Fe-rich olivine in dunite.

The overall misfit between any model profiles assuming a constant cooling rate and the observation is large (Fig. 9a), suggesting an increase in
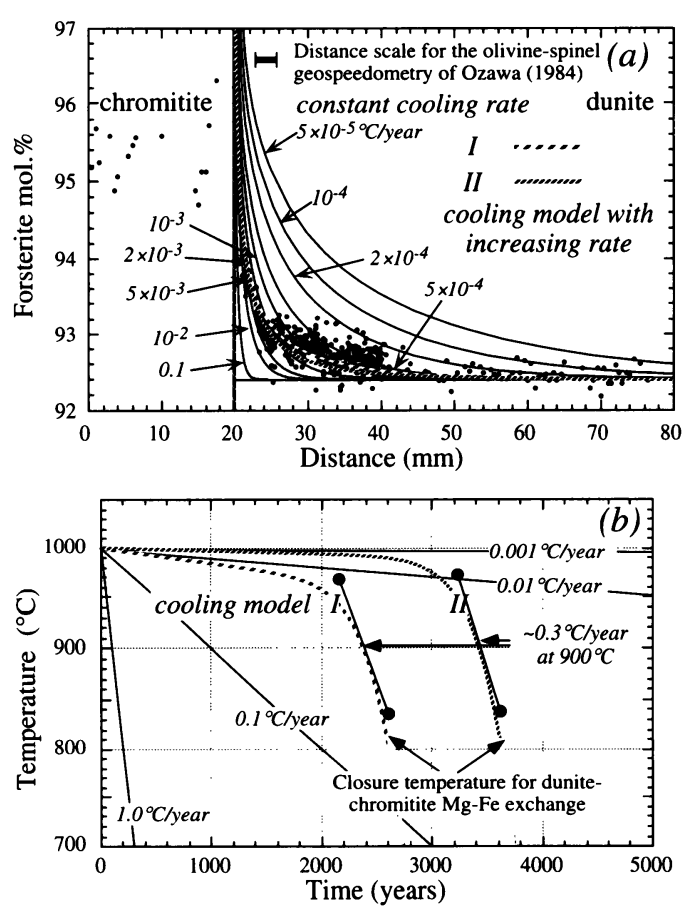

Fig. 9 Cooling models (I and II shown in (b)) with changeable rate to fit the Fo variation. The models assume rapid diffusion in the chromitite layer and the homogeneous initial condition $\mathrm{Fo}=92.4$. The composition dependent Fe-Mg interdiffusion coefficient after Misener ${ }^{15)}$ and the $\mathrm{Mg}-\mathrm{Fe}$ partition coefficient between olivine and spinel after Fabriès ${ }^{29)}$ were used. Note that any cooling models with constant rate does not reproduce the observation.

the cooling rate by more than one order of magnitude. This is because the decrease in cooling rate produces much gentler zoning profile. If the assumption of the initial $\mathrm{Fo}=92.4$ is correct, the Fo profile can be reproduced by slower cooling rate as low as $0.001-0.01^{\circ} \mathrm{C} /$ year at $\sim 1000^{\circ} \mathrm{C}$ and increasing rate by one or two orders of magnitude during $\sim 200^{\circ} \mathrm{C}$ temperature drop (Fig. 9b). The tendency of the increasing cooling rate is consistent with the dunite-chromitite geospeedometry ${ }^{2}$.

The increasing cooling rate as cooling proceeds is contrasting to the thermal history inferred for a contact aureole ${ }^{3)}$, where the cooling rate gradually decreases. The inferred increase of cooling rate may be explained by two scenarios. Cooling of the Iwanai-dake mass was accelerated in the shallower level probably by nearly constant uplift of the mantle material. Alternatively, the initial slow cooling represents static cooling after the melting event, 
which was followed by an ascent of the complex that caused rapid cooling at lower temperatures.

\section{Conclusion}

In order to estimate the high temperature thermal history that cannot be obtained by conventional geospeedometry, there are two possible ways; the first is to find a mineral that has an extraordinary high activation energy for diffusion of a component and the second is to increase a distance scale for the geospeedometry. The first approach fails because the activation energy, which is related to the frequency factor of Arrhenius relations for diffusion by the compensation law, is usually less than $800 \mathrm{~kJ} / \mathrm{mole}$. The second method is more promising but gives rise to many difficulties that have to be overcome before the successful application of this method.

Among these difficulties, the role of grain boundary diffusion, along which material transportation may be significant, is evaluated by a simple 2-D model. Analysis of the model shows that the grain boundary diffusion is not important for slowly cooled rocks if the grain size is larger than a few hundreds $\mathrm{mm}$ and if diffusion along grain boundary with $\sim 1 \mathrm{~nm}$ thickness is not faster than lattice diffusion by 5 orders of magnitude.

The method of increasing distance scale for geospeedometry is applied to a dunite-chromitite contact from the Iwanai-dake mass, Hokkaido. The distance scale is $\sim 10 \mathrm{~cm}$, which is almost 100 times larger than the maximum size of spinel grain used for olivine-spinel geospeedometry. The maximum temperature calculated for a pair of spinel in chromitite and the most Fe-rich olivine in dunite gives $1000^{\circ} \mathrm{C}$, suggesting the initial temperature higher than this value. The estimated cooling rate decreases from $\sim 0.001^{\circ} \mathrm{C} /$ year to $0.3^{\circ} \mathrm{C} /$ year during cooling from 1000 to $900^{\circ} \mathrm{C}$.

Further studies needed to devise useful high temperature geospeedometry for slowly cooled rocks are to find suitable approximation of diffusion in a polycrystalline and multi-phase system and simultaneous inversion of cooling history and magmatic processes.

Acknowledgment: I thank Kiyoshi Fujino for organizing the Sanko-Symposium on disequilibrium processes in solid earth science in the 1997 fall meeting held in Sendai and giving me the chance to struggle with this paper. I am indebted to Hiroko Nagahara for discussion and critical reading of the manuscript. Comments by an anonymous reviewer is helpful to improve the paper. I also thank to Katsuyuki Ishibashi for photographs of the studied sample and to Hideto Yoshida for EPMA analyses at the Geological Institute of the University of Tokyo.

\section{References}

1) Lasaga, A. C. (1983): Geospeedometry: an extension of geothermometry. In: Saxena, S. K.(ed.), Kinetics and Equilibrium in Mineral Reactions, 3, Springer-Verlag, New York, pp. 81-114.

2) Ozawa, K. (1984a): Olivine-spinel geospeedometry: Analysis of diffusion-controlled $\mathrm{Mg}-\mathrm{Fe}^{2+}$ exchange. Geochim. Cosmochim. Acta, 48, 2597-2611.

3) Lasaga, A. C. and Jianxin, J. (1995): Thermal history of rocks: P-T-t paths from geospeedometry, petrologic data, and inverse theory techniques. Amer. Jour. Sci., 295, 697 -741 .

4) Lasaga, A. C., Richardson, S. M., and Holland, H. D. (1977): The mathematics of cation diffusion and exchange between silicate minerals during retrograde metamorphism. In: Saxena, S. K and Bhattacharji, S. (eds.). Energetics of Geological Process, Springer Verlag, New York, pp. 353-388.

5) Onorato, P. I. K., Hopper, R. W., Yinnon, H., Uhlmann, D. R., Taylor, L. A., Garrison, J. R. and Hunter, R. (1981): Solute partitioning under continuous cooling conditions as a cooling rate indicator. Jour. Geophys. Res., 86, 6511-6518.

6) Ozawa, K. (1983): Evaluation of olivine-spinel geothermometry as an indicator of thermal history for peridotites. Contrib. Mineral. Petrol., 82, 52-65.

7) Dodson, M. H. (1973): Closure temperature in cooling geochronological and petrological systems. Contrib. Mineral. Petrol., 40, 259-274.

8) Ehlers, K. and Powell, R. (1994): An empirical modification of Dodson's equation for closure temperature in binary systems. Geochim. Cosmochim. Acta, 58, 241-248.

9) Dodson, M. H. (1976): Kinetic processes and thermal history of slowly cooling solids. Nature, 259, 551-553.

10) Winchell, P. (1969): The compensation law for diffusion in silicates. High Temperature Science, 1, 200-215.

11) Hofmann, A. W. (1980): Diffusion in natural silicate melts: a critical review. In: Hargraves, R. B. (ed.), Physics of Magmatic Processes, Princeton University Press, Princeton, New Jerseypp. 385-417.

12) Freer, R. (1980): Bibliography: Self-diffusion and impurity diffusion in oxides. Jour. Material. Sci., 15, 803-824.

13) Freer, R. (1981): Diffusion in silicate minerals and glasses: A data digest and guide to the literature. Contrib. Mineral. Petrol., 76, 440-454.

14) Fujino, K., Furo, K. and Momoi, H. (1988): Preferred orientation of antiphase boundaries in pigeonite as a cooling ratemeter. Phys. Chem. Minerals, 15, 329-335. 
15) Misener, D. J. (1974): Cationic diffusion in olivine to $1400^{\circ} \mathrm{C}$ and 35 kbar, In: Hofmann, A. W., Giletti, B. J., Yoder, H. S. Jr. and Yund, R. A. (ed.), Geochemical Transport and Kinetics, Carnegie Inst. of Washington, Washington, D. C., pp. 117-129,

16) Chakraborty, S. (1997): Rates and mechanisms of $\mathrm{Fe}-\mathrm{Mg}$ interdiffusion in olivine at $980^{\circ}-1300^{\circ} \mathrm{C}$. Jour. Geophys. Res., 102, 12317-12331.

17) Brady, J. B. (1983): Intergranular diffusion in metamorphic rocks. Amer. Jour. Sci., 283-A, 181-201.

18) Joesten, R. (1991): Grain-boundary diffusion kinetics in silicate and oxide minerals. In: Ganguly, J., (ed.), Diffusion, Atomic Ordering, and Mass Transport, 8, SpringerVerlag, New York, pp. 345-395.

19) Sutton, A. P. and Balluffi, R. W. (1995): Interfaces in Crystalline Materials. pp. 819, Clarendon Press, Oxford.

20) Harrison, L. G. (1961): Influence of dislocations on diffusion kinetics in solids with particular reference to the alkali halides. Trans. Faraday Soc., 57, 1191-1199.

21) Fisher, J. C. (1951): Calculation of diffusion penetration curves for surface and grain boundary diffusion. Jour. Appl. Phys., 22, 74-77.

22) Carnahan, B., Luther, H. A. and Wilkes, J. O. (1969): Applied Numerical Methods, pp.981, John Wiley \& Sons,
Inc., New York.

23) Maxwell, C. (1873): Treatise on electricity and magnetism Vol. I. pp. 365. Oxford University Press, London.

24) Crank, J. (1956): The Mathematics of Diffusion. pp.414, Oxford University Press, London.

25) Bear, J. (1972): Dynamics of Fluids in Porous Media. Elsevier, New York, pp764.

26) Ozawa, K. (1984b): Compositional zoning of spinel investigated by computer aided micro analyzer (CMA). JEOL News, 22E, 19-24.

27) Irvine, T. N. (1965): Chromian spinel as a petrogenetic indicator. Part I, theory. Can. Jour. Earth Sci., 2, 648-672.

28) Moutte, J. (1982): Chromite deposits of the Tiébaghi ultramafic massif, New Caledonia. Economic Geol., 77, 576591.

29) Fabriès, J. (1979): Spinel-olivine geothermometry in peridotites from ultramafic complexes. Contrib. Mineral. Petrol., 69, 329-336.

30) Nakamura, M. (1995): Residence time and crystallization history of nickeliferous olivine phenocrysts from the Yatsugatake volcanoes, Central Japan: Application of a growth and diffusion model in the system $\mathrm{Mg}$-Fe-Ni. Jour. Volc. Geotherm. Res., 66, 81-100.

\title{
冷却地質速度計における高温限界の拡張
}

\author{
小澤 一仁
}

要旨: 岩石の冷却速度を推定するために今まで提案さ れた冷却地質速度計には，冷却史を推定することので きない最高温度が必ず存在する。この高温限界は, 地 質速度計に関わるカイネティクスと冷却速度によって 決まってくる．例えば，かんらん石とスピネル間での $\mathrm{Mg}-\mathrm{Fe}$ の交換反応のカイネティクスを利用したかんらん 石一スピネル地質速度計では, スピネルの一般的最大 粒径が数mmであるので, かんらん岩の冷却速度として ごく普通の $10^{-40} /$ 年というゆっくりした冷却の場合に は, 高々 $800^{\circ} \mathrm{C}$ 以下の冷却史しか推定できない。この ように低い高温限界をより高くする方法で最も有力な ものは, 速度計の距離スケールを大きくすることであ る、鉱物の粒子の大きさには限界があるが, 鉱物の量 比の変化によってできる岩石のマクロな構造には, こ のような限界がなく, 原理的にはソリダス温度までの 冷却史を推定できるはずである。ただし，このような
マクロ構造を冷却速度計として用いるためには，岩石 という多粒子・多相系に伴う様々な複雑さや初期条件 の不明確さという困難を乗り越えなくてはならない. この論文では, 多粒子系の問題を検討した後, かんら ん石一スピネル地質速度計を拡張し, 北海道岩内岳か んらん岩体産のダナイトとクロミタイト層の境界につ いて, カンラン石のFe-Mg比の変化を利用してょり高温

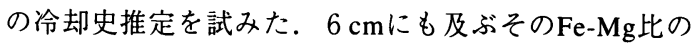
変化を一次元の拡散係数の組成依存性と冷却速度の時 間依存性を考慮した拡散モデルで解析した。このダナ イトークロミタイト地質速度計によって, 岩内岳かん らん岩体は約 $1000^{\circ} \mathrm{C}$ から $900^{\circ} \mathrm{C}$ まで冷却速度が $0.01^{\circ} /$ 年以下から約 $0.3^{\circ} /$ 年程度まで増加したことがわかっ た.この冷却史から，かんらん岩体は融解過程終了後 の冷却に引き続き急速に上昇をしたと考えられる。 